\title{
The Person-Case Constraint and the Inverse Agreement Constraint are manifestations of the same Inverse Topicality Constraint
}

\section{Goal}

This paper first claims that the Inverse Agreement Constraint and the Person-Case Constraint attested in overlapping sets of Uralic languages are manifestations of the same Inverse Topicality Constraint, requiring that the structural hierarchy of topicalized constituents correspond to the ranking of their referents in the Animacy/Topicality Hierarchy. Then it argues that it is the hypothesized Inverse Topicality Constraint that also underlies the PersonCase Constraints restricting the cooccurrence of clitics in ditransitive and ergative-absolutive constructions across languages. It is shown that alternative analyses of the Person-Case Constraint, e.g., those deriving it from the mechanism of multiple Agree, cannot account for the whole range of data attested.

The paper is structured as follows: Section 2 introduces the Inverse Agreement Constraint. Section 3 demonstrates that it is a concomitant of Differential Object Marking in various Uralic languages. It functions as an Inverse Topicality Constraint, harmonizing the structural hierarchy of the topicalized subject and object, and the ranking of their referents in the Animacy/Topicality Hierarchy. Section 4 shows that the Ugric branch of the Uralic family has preserved a Person-Case Constraint, as well, which represents another version of the Inverse Topicality Constraint. Section 5 surveys the manifestations of the Person-Case Constraint across languages, and the theories proposed to account for them. Section 6 shows that these theories cannot explain the Ugric facts, whereas the proposed Inverse Topicality Constraint can account for the data covered by the Inverse Agreement Constraint and the Person-Case Constraint crosslinguistically.

\section{The Inverse Agreement Constraint}

The Inverse Agreement Constraint was first observed by Comrie (1980) in the ChukchiKamchatkan languages. In these languages, the verb agrees with both the subject and the object, provided the subject is higher ranked in the Animacy Hierarchy than the object. That is, object-verb agreement is restricted as follows:

\section{(1) Inverse Agreement Constraint}

An object agreeing with a verb must be lower in the Animacy Hierarchy than the subject agreeing with the same verb. 
The animacy hierarchies of these languages are versions of the person hierarchy in (2), ranking the participants of a discourse according to the activity of the role they fulfil (with the speaker more active than the listener(s), and the listener(s) more active than those not present):

\section{(2) Animacy Hierarchy}

$$
1 \mathrm{SG}>1 \mathrm{PL}>2 \mathrm{SG}>2 \mathrm{PL}>3 \mathrm{SG}>3 \mathrm{PL}
$$

The language-specific manifestations of this Animacy Hierarchy are usually two- or threelevel hierarchies, collapsing some adjacent grades of the hierarchy in (1).

Chukchee, Koryak, and Kamchadal can avoid violating the Inverse Agreement Constraint in two ways. They can supply the verb with an inverse prefix indicating that the Inverse Agreement Constraint is suspended. Alternatively, the verb only agrees with its subject, i.e., object-verb agreement is blocked.

The Inverse Agreement Constraint has also been pointed out in Hungarian, a Ugric language of the Uralic family (É. Kiss 2005, 2013). In Hungarian, the verb agrees with its object if it is definite. As expected, a 3rd person pronominal object always elicits agreement, whatever the person of the subject is (see (3)). (In 1st and 2nd person singular, a portmanteau morpheme represents both subject and object agreement. In the other cases, a separate $-j(a)$ morpheme stands for object agreement. In 3rd person singular, the subject agreement suffix is zero . $)^{1}$

$\begin{array}{llllll}\text { (3) Én } & \text { lát-om } & \text { öt/öket. } & \text { Mi } & \text { lát-j-uk } & \text { öt/öket. } \\ \text { I } & \text { see-OBJ.1SG } & \text { her/them } & \text { we } & \text { see-OBJ-1PL } & \text { her/them } \\ \text { Te } & \text { lát-od } & \text { öt/öket. } & T i & \text { lát-já-tok } & \text { öt/őket. } \\ \text { you } & \text { see-OBJ.2SG } & \text { her/them } & \text { you } & \text { see-OBJ-2PL } & \text { her/them } \\ \text { Pál } & \text { lát-ja-0 } & \text { öt/öket. } & \text { A fiúk } & \text { lát-já-k } & \text { öt/őket. }\end{array}$

\footnotetext{
${ }^{1}$ The object agreement morpheme has the allomorphs $j(a) / i / j / j e$, whose distribution is determined by vowel harmony, among others (see Rebrus 2000). Compare:

\begin{tabular}{|c|c|c|c|}
\hline íro-m & 'write-OBJ.1SG' & ismere- $m$ & 'know-OBJ.1SG' \\
\hline iro-d & 'write-OBJ.2SG' & ismere-d & 'know-OBJ.2SG' \\
\hline ir-ja-0 & 'write-OBJ-3SG' & ismer-i -0 & 'know-OBJ-3SG' \\
\hline$-j-u k$ & 'write-OBJ-1PL' & ismer-j -uk & 'know-OBJ-1PL' \\
\hline -já-tok & 'write-OBJ-2PL' & ismer-i -tek & 'know-OBJ-2PL' \\
\hline$i r-\mathbf{j a ́}-k$ & 'write-OBJ-3PL' & $i s m e r-\boldsymbol{i}-k$ & 'know-OBJ-3PL' \\
\hline
\end{tabular}
}


Whether a 1st or 2nd person object triggers agreement depends on the person of the subject. The verb agrees with its 2 nd person object only if the subject is 1 st person singular (4).
(4) Én lát-l-ak téged/titeket. ${ }^{2}$
I see-2OBJ-1SG you $_{\mathrm{SG}} / \mathrm{you}_{\mathrm{PL}}$

A 1st person singular object never elicits agreement:
(5) Te lát-sz engem.
Ti lát-tok engem.
you see-2sG me
you $_{\mathrm{PL}}$ see-2PL me
Ö lát-0 engem.
Ök lát-nak engem.
he see-3SG me
they see-3PL me

Interestingly, we have object-verb agreement in the case of a 1SG subject and a 1PL object, as well as in the case of a 2SG subject and a 2PL object (6a,b). In the reverse cases (a 1PL subject and a 1 SG object, and a 2PL subject and a 2SG object), however, object-verb agreement is blocked (7a,b) (see den Dikken et al. 2001):

(6)
a. Én minket ajánl-om
/*ajánl-ok.

I us recommend-OBJ.1SG/recommend-1SG

'I recommend us.'
b. Te titeket ajánl-od /*ajánl-asz? ${ }^{3}$
you $_{\mathrm{SG}}$ you $_{\mathrm{PL}}$.ACC recommend-OBJ.2SG/recommend-2SG
'Do you SG recommend you guys?
(7) a. Mi engem választ-unk/*választ-ju-k.
we me elect-1PL /elect-OBJ-1PL

\footnotetext{
${ }^{2}$ The morpheme agreeing with a 2 nd person object is $-l-$. Only a verb with a $1 \mathrm{SG}$ subject can bear this morpheme.

${ }^{3}$ Den Dikken et al. (2001) analyze the pattern in (6) as inclusive reference, and derive it from restrictions on binding.
} 
'We elect me.'

b. Ti téged választ-otok/*választ-já-tok?

you $_{\mathrm{PL}} \mathrm{you}_{\mathrm{SG}}$. ACC elect- $2 \mathrm{SG}$ /elect- OBJ-2SG

'Do you guys elect you $\mathrm{SG}_{\mathrm{G}}$ ?

These facts follow from the version of the Animacy Hierarchy in (8):

(8) Animacy Hierarchy (Hungarian)

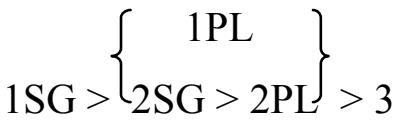

According to Comrie (1980), languages handle situations involving a subject and an object representing the lowest level of the Animacy Hierarchy in different ways. Hungarian suspends the Inverse Agreement Constraint in that case, as shown by the caveat in (9). Since the Animacy Hierarchy is a hierarchy of the participants of the discourse, the formulation of the Inverse Agreement Constraint proposed for Hungarian refers to it as a hiearchy of referents:

(9) Inverse Agreement Constraint (Hungarian)

The referent of an object agreeing with a verb must be lower in the Animacy Hierarchy than the referent of the subject agreeing with the same verb, unless both the subject and the object represent the lowest level of the Animacy Hierarchy.

\section{The Inverse Agreement Constraint is an Inverse Topicality Constraint}

\subsection{Differential Object Marking in Uralic}

In Hungarian, where object-verb agreement has undergone a change of function (É. Kiss 2012), the motivation underlying the Inverse Agreement Constraint has become obsolete. However, the Ugric sister languages of Hungarian, Khanty and Mansi, as well as the Samoyedic languages of the Uralic family, have preserved its original function - as shown by Nikolaeva (2001). In the strictly SOV Khanty sentence, the subject is also the (primary) topic, whereas the object functions either as a secondary topic or as a focus. Object-verb agreement encodes the secondary topic role of the object. This is as expected in view of the theory of Givón (1975), who claims - on the basis of data from Bantu languages, Creole languages, child language, etc. - that verbal agreement originated from topic-doubling pronouns. (The - 
ja-3SG object agreement suffix of Hungarian is actually cognate with the reconstructed Proto-Uralic 3SG accusative pronoun - cf. Honti (2009).)

Compare the following Khanty minimal pair:

a. $k u$ rit $t u-s$

man boat take-PAST.3SG

'The man took a boat.'

b. $k u$ rit $t u-s-t$

man boat take-PAST-OBJ.3SG

'The man took the boat.'

(Khanty, Gulya 1970)

In (10a), the object carries new information, i.e., it is focus eliciting no object-verb agreement. In (10b), where the verb agrees with the object, the object is interpreted as definite, referring to a previously mentioned boat.

In all-new sentences answering the question What happened?, the object counts as focus, hence it does not elicit agreement on the verb:

(11) What happened?

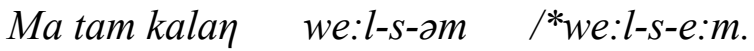

I this reindeer kill-PAST-1SG/kill-PAST-OBJ.1SG

'I killed this reindeer.'

(Khanty, Nikolaeva 2001: (14))

If the sentence contains a narrow focus other than the object, the object is part of the presupposition, hence it elicits agreement:
Ma ta:lax
ta:ta a:kat-l-e:m
$/ * a: k \partial t-l-\partial m$
anta to:ta.
I mushroom here collect-PRES-OBJ.1SG/collect- PRES-1SG not there

'I collect mushrooms HERE, not THERE.'

(Khanty, Nikolaeva 2001: (32))

The secondary topic is a familiarity topic; it conveys contextually or situationally given information. The criteria of givenness is also satisfied if the possessor of the object is given, including the case when it is coreferent with the clause-mate subject. In (13), the topic interpretation of the object is licensed by its coreference with the subject. In other words, object-verb agreement enforces the given, i.e., coreferent, interpretation of the possessor. 


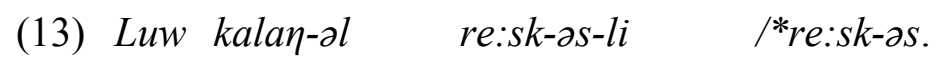

he reindeer-3SG hit-PAST-OBJ.3SG/*hit-PAST.3SG

' $\mathrm{He}_{\mathrm{i}}$ hit his $\mathrm{i}_{\mathrm{i} / \mathrm{j}}$ reindeer.'

(Khanty, Nikolaeva 2001: (45b))

Nikolaeva (2001) examined the information status of the object in nearly 1100 Khanty transitive clauses recorded by Pápay (1906-8). 412 of the clauses contain a non-agreeing object, and 677 of them contain an agreeing object. Among the agreeing (i.e., topical) objects, $87 \%$ are contextually given, and an additional $7 \%$ have a contextually given possessor.

Among the non-agreeing, i.e., focused, objects, the proportion of previously activated objects is $11 \%$.

The agreeing object of the Khanty sentence is always secondary topic, i.e., it represents given information, but it is never the only topic; it is not the constituent whose referent the sentence is about. If the D-structure object is intended to represent the primary topic, the sentence is passivized. Compare:

(14) a. (Luw) Juwan re:sk-əs.

he Ivan hit- PAST.3SG

'He hit Ivan.'

b. Juwan xoj-na re:sk-əs-a.

Ivan who-LOC hit-PAST-PASS.3SG

'Who was Ivan hit by?'

(Khanty, Nikolaeva 1999: (155)-(156))

(15) a.*Xoj tam xu:j an wa:nt-əs /wa:nt-əs-li.

who this man not see-PAST.3SG/see-PAST-OBJ.3SG

'Nobody saw this man.'

b. Tam xu:j xoj-na an wa:n-s-a.

this man who-LOC not see-PAST-PASS.3SG

'This man was not seen by anybody.'

(Khanty, Nikolaeva 2001, (28a-b))

The secondary topic status of the agreeing object follows from its structural position. In the SOV Khanty sentence, a non-agreeing object is strictly preverbal, and the oblique arguments and adjuncts are to be found between the object and the topicalized subject. When the object is secondary topic eliciting verbal agreement, it is extracted from the VP into a position 
preceding the oblique arguments and the VP-adjuncts, where it is still preceded and ccommanded by the subject, functioning as the primary topic (Nikolaeva 1999: 63-69).

The type of differential object-verb agreement observed in Khanty, encoding the information status of the object, is operative in other languages of the Uralic family, as well. It is attested in Mansi (Vogul), the other Ugric sister language of Hungarian (Skribnik 2001, Sipöcz 2013, Virtanen 2014; 2015). Compare (16) and (17). In (16), the object of the Mansi sentence introduces a new referent, hence it elicits no verbal agreement. In (17), the object counts as given, and as a secondary topic it evokes object-verb agreement:

(16) Toonøtäätøl såjrøng påly-låpsyøx sågrøp-øs. then white wood-chip split-PST.3SG 'Then he split a white chip of wood.' (Eastern Mansi, Virtanen 2014: (8))

\section{(17) Jiiw-ty-mø sok juw-tåt-øs-te. ${ }^{4}$ wood-PL-ACC all home-bring-PAST-OBJ.3SG}

'He brought all the wood home.'

The secondary topic role marked by agreement on the verb is not restricted to theme arguments (Skribnik 2001, Sipőcz 2012). As the Northern Mansi examples of Skribnik (2001) illustrate, a benefactive, an instrument, or even a goal can be construed as a secondary topic eliciting agreement on the verb, owing to a kind of 'indirect object shift'. A topicalized indirect object bears no morphological case; at the same time, the theme argument ousted from the position of the direct object assumes instrumental case:

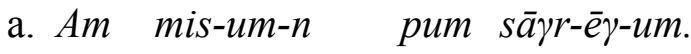

I cow-1SG-DAT hay cut-PRES-1SG

'I cut hay for my cow.'

b. Am mis-um pum-al sāyr-i-l-um.

I cow-1SG hay-INSTR cut-PRES-OBJ-1SG

'I supply my cow with hay.'

\footnotetext{
${ }^{4}$ As illustrated by (18)-(19), the topical object in Eastern Mansi receives accusative case. Differential object marking in Eastern Mansi will be discussed in section 4.
} 
(19) a. Am tul'ōwl-um-əl rātaśl-ē $\gamma-u m$.

I finger-1SG-INSTR tap-PRES-1SG

'I am tapping with my finger.'

b. Am tul'ōwl-um rātaśl-i-l-um.

I finger-1SG tap- PRES-OBJ-1SG

'I am tapping my finger.'

(20) a. Taw $\chi \bar{a} p-\partial n \quad j o \chi t-\partial s$.

he boat-DAT come-PAST.3SG

'He came to the boat.'

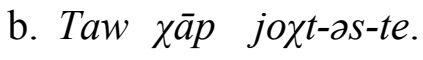

he boat come-PAST-OBJ.3SG

'He reached the boat.'

(Northern Mansi, Skribnik 2001)

\subsection{The Inverse Agreement Constraint in Uralic}

The clarification of the role of Ugric differential object-verb agreement has also made it clear when and why the Inverse Agreement Constraint is evoked. It is elicited when the clause contains two topics; when both the subject and the object are extracted from the VP.

The Animacy Hierarchy underlying the Inverse Agreement Constraint is nondistinct from the universal Topicality Hierarchy, i.e., the likelihood of various NP arguments being the topic of sentences (cf. Moravcsik 1974, Givón 1975, 1983, Aissen 1999). Hence, what the Inverse Agreement Constraint blocks is that the secondary topic be higher ranked in the Animacy/Topicality Hierarchy than the structurally more prominent primary topic (É. Kiss 2013):

\section{(21) Inverse Topicality Constraint}

In a construction with two topics, the structural hierarchy of the topics cannot contradict the ranking of their referents in the Animacy/Topicality Hierarchy.

Violatons of (21) can be avoided by construing the object outranking the subject in the Animacy/Topicality Hierarchy as a focus, i.e.:

(22) An object more animate/more topical than the subject of the same clause can only be construed as a focus. 
According to Givón (1975), topicalized object - verb agreement is often reinterpreted as definite object - verb agreement, given that topics are definite in most cases. This is what happened in Hungarian, too, in the post-Ugric, Proto-Hungarian period. However, as illustrated by Marcantonio (1985) and É. Kiss (2014), traces of the original topic-marking function of the Hungarian objective conjugation are still attested in the Old Hungarian period. Though Hungarian has lost the topic-encoding function of object-verb agreement, it has preserved the Inverse Topicality Constraint as a linguistic fossil.

In most dialects of the two sister languages of Hungarian, Khanty and Mansi, the opposite happened: they have preserved the topic-encoding function of object-verb agreement, ${ }^{5}$ but have lost the Inverse Topicality Constraint. Eastern Khanty is an exception; it still displays both differential object-verb agreement, and the Inverse Agreement Constraint. Thus 1st and 2nd person pronominal objects never elicit agreement (Dalrymple \& Nikolaeva 2011: 196; Márta Csepregi p.c.) - see (23a,b). In the case of 3rd person pronominal objects, however, we find object-verb agreement (unless the pronoun is focussed) - see (24).

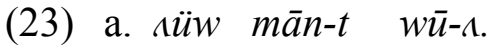

he I-ACC see-PRS.3SG

'He sees/knows me.'

b. $\wedge \ddot{u} w \quad n \ddot{u} \eta-a t \quad w \bar{u}-\Lambda$. he you-ACC see-PRS.3SG

'He sees/knows you ${ }_{\mathrm{SG}}$ '

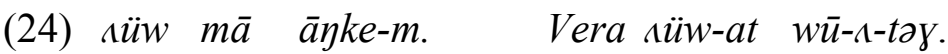
she I mother-1SG Vera she-ACC know-PRS-OBJ.3SG 'She is my mother. Vera knows her.'

The version of the Animacy Hierarchy underlying the Inverse Topicality Constraint in Eastern Khanty is slightly different from that attested in Hungarian: 1st and 2nd person pronominal objects never elicit object agreement whatever the person of the subject. Whereas in Hungarian, the configuration '1SG subject, 2SG/PL object' results in object-verb

\footnotetext{
${ }^{5}$ This only holds for patient and theme objects (Dalrymple \& Nikolaeva 2011: 149). Goal, recipient and causee objects always trigger agreement.
} 
agreement (see (4) above), in Eastern Khanty it does not (see (25)), which follows if 1st and 2nd person are collapsed into a single level in the hierarchy.

(25) $M \bar{a} \quad n \ddot{u} y-a t \quad w \bar{u}-\iota-\partial m$.
I $\quad$ you-ACC $\quad$ see-PRS-1SG
'I see/know you ${ }_{\mathrm{SG}}$,

The Samoyedic languages of the Uralic family, among them Tundra Nenets, have also preserved both components of this grammatical system: they mark the secondary topic role of the object by verbal argeement, and the Inverse Topicality Constraint prevents 1 st and 2nd person pronouns from assuming a secondary topic role (Dalrymple and Nikolaeva 2011, Nikolaeva 2014). Tundra Nenets differential object-verb agreement is illustrated by the minimal pair in (26). In (26a), the object is secondary topic; in (26b), it is focus:

(26) a. N'īs'a-m'i yəno-m s'ertas-da? father-1SG boat-ACC do-OBJ.3SG

'Has my father finished making the boat?'

b. N'ī s'a-m'i yano-m s'erta ? father-1SG boat-ACC do.3SG

'Did my father make a boat?' (Nikolaeva 2014: 207)

Inherently focused objects, among them interrogative pronouns, indefinite and negative pronouns, only phrases, and too phrases, never elicit agreement. E.g.:

a. Wera-r'i-m lad'o.

Wera-LIMIT.ACC hit.3SG

'He hit only Wera.'

b. *Wera-r'i-m lad’o-da.

Wera-LIMIT.ACC hit-OBJ.3SG

'He hit only Wera.'

(Nenets, Nikolaeva 2014: 205)

As follows from the Inverse Agreement Constraint, verbal agreement is blocked in the case of 1 st and 2 nd person objects. Compare (28a), which contains a dual 3rd person object 
eliciting verbal agreement, with (28b), which contains a dual 1st person object eliciting no agreement:

(28) a. yəno-x $x^{\circ}$ man'iyeya-xəyu- $n^{\circ}$.

boat-DU.ACC see-DU.OBJ-1SG

'I see the (two) boats.'

b. Pida s’id’n'ih lad’o.

he we.DU.ACC hit.3SG

'He hit the two of us.'

(Nikolaeva 2014: 202)

The situation is similar in the other Samoyedic languages, e.g., in Selkup. In the Selkup example in (29a), the verb optionally agrees with the 3rd person object. In (29b), where the object is 2 nd person, object-verb agreement is impossible.

(29) a. Tәp kanap qontyrtenta/qontyrtentyyyty. he dog.ACC see.FUT.3SG/see.FUT.OBJ.3SG 'He will see a/the dog.'

b. Tәp šinty qontyrtenta/*qontyrtentyyyty. he you.ACC see.FUT.3SG/see FUT.OBJ.3SG 'He will see you.'

(Kuznecova et al. (1982: 235), cited by Dalrymple \& Nikolaeva (2011: 199-201))

Differential object agreement encoding the topicality of the object is not unique to the Uralic languages; as shown by Dalrymple and Nikolaeva (2011), it is common all over the world. Kallulli (2008) and Dočekal and Kallulli (2012) also analyze object clitic doubling as agreement encoding the topicality of the object in Albanian, Greek, Romanian and Spanish. The Inverse Agreement Constraint, blocking the topic-marking of 1st and 2nd person objects, thereby preventing secondary object topics from outranking primary subject topics in the topicality hierarchy, has also been observed in many of the languages displaying differential object-verb agreement, among them Waris in Trans-New Guinea (Brown 1988); Sursunga (Oceanic), Nanggu (Papuan), Waura, Parecis (Carib), etc. (Siewierska 2004:150).

\section{The Person-Case Constraint (PCC) in Ugric}


According to Dalrymple and Nikolaeva (2011: 2), differential object-verb agreement is merely one of the possible manifestations of the more general phenomenon of differential object marking. The other possibility is to mark the topic role of the object on the object by a case suffix. Differential object-verb agreement and differential accusative marking can also go hand in hand, encoding the secondary topic status of the object both on the verb and on the object. This is also the case in Eastern Mansi - see (16)-(17) above. As shown by Virtanen (2014), in the SOV Eastern Mansi sentence the subject is topic, and the object is either focus (30a) or secondary topic (30b). The object is case-marked if and only if it is topic:

(30) a. Kom jowt-nyõ̃̃l wø-s.

man bow-arrow take-PAST.3SG

'The man took a bow and an arrow'

(Eastern Mansi, Virtanen 2014: (17))

b. Õ̃w-mø öät kont-iiløm. door-ACC NEG find-OBJ.1SG

'I can't find the door.'

(Eastern Mansi, Virtanen 2014: (11))

1 st and 2nd person objects $(31 \mathrm{a}, \mathrm{b})$, and objects anchored to a 1 st or 2 nd person possessor (32) are always caseless:

(31) a. Ö̈̈nøm jål-ääl-ääløn.

I.1SG down-kill-IMP.OBJ.2SG

'Kill me!'

(Eastern Mansi, Virtanen 2014: (15))

b. Om nään jorøl tảt-øs-løm tøg.

I you.2SG on.purpose bring-PAST-OBJ.1SG here

'I brought you here on purpose.'

(Eastern Mansi, Virtanen 2014: 42)

(32) Ä̈̈k-øn komøly woåxtl-øs-løn!

uncle-2SG how leave- PAST-OBJ.2SG

'How could you leave your uncle!' （Eastern Mansi, Virtanen 2014: (21))

The pronominal objects in $(31 \mathrm{a}, \mathrm{b})$ bear possessive suffixes agreeing with the person and number of the given pronoun, i.e., they mean literally 'my I', 'your you'. In Mansi, like in most Uralic languages, possessive endings also have a non-possessive, determiner-like 
function (Nikolaeva 2002). Crucially, however, the possessive endings are not accusative morphemes; they can be combined with an accusative marker in the case of 3rd person pronouns and in the case of lexical nouns, as is illustrated in $(33 a, b)$ :

(33) a. tääw-øtääm

he-3SG.ACC (Eastern Mansi, Forsberg 2007: 55)

'him'

b. Sågrøp-øtääm kont-øs-tø.

axe-3SG.ACC find-PAST-OBJ.3SG

'He found his axe.' $\quad$ (Eastern Mansi, Virtanen 2014: (23))

As Nikolaeva (2002) demonstrates, non-possessively used possessive agreement morphemes can have three functions in the Uralic languages. 3rd person genitive endings can have an identifying, deictic role, expressing that the referent of the noun phrase bearing the possessive morpheme is the one pointed at in the given situation. 1st and 2nd person endings have an associative function, expressing that the speaker or the addressee is conceptualized as the reference point in the situation. Finally, the possessive ending can also express contrast.

The grammaticalized possessive endings of 1 st and 2nd person objects in Hungarian, Mansi and Khanty can be traced back to either the associative or the contrastive function of the possessive ending. The possessive ending of 1 st and 2 nd person objects could encode originally that though the 1 st or 2 nd person participant is not the subject-topic of the sentence, it is still the reference point of the situation. Alternatively (or simultaneously) it could originally mark the contrastive, focus function of the 1st or 2nd person object - reflecting the fact that 1 st and 2 nd person objects could not function as secondary topics; they were foci (at least in the presence of a 3 rd person subject). The assumption that the possessive morpheme of 1 st and 2 nd person pronouns can be the grammaticalized marker of their focus status is supported by a related observation showing their inherent focus role: although pro-dropped topics, among them phonologically null object pro's are common in Mansi, Virtanen (2014: 406) did not find any 1st person singular object pro in her corpus of 2000 sentences, and she attested 2nd person object pro's only in the presence of a 1st person subject.

The interdependence of object marking and object-verb agreement is almost complete in the more than 2000 Eastern Mansi sentences analyzed by Virtanen $(2014 ; 2015)$. The rate of accusative-marked objects among the objects not eliciting agreement is $7 \%$, and the rate of overt uncasemarked nominal objects among the objects eliciting agreement is $13 \%$. Some of 
the mismatches involve a 1 st or a 2 nd person object, which are grammaticalized to reject accusative marking, but can, nevertheless, elicit agreement when they are contextually given. The mismatch between object marking and object agreement may often be merely apparent. E.g., in the following sentence, the object eliciting agreement may well be a silent accusative pro; the postverbal nominative object appears to be an afterthought:

$\begin{array}{lllll}\text { Wisy-kom } & \text { kontø-s-tø } & \text { jäg-ø } & \text { tarot-ääm } & \text { nеepøx. } \\ \text { young.man } & \text { find-PRET-OBJ.3SG } & \text { father-3SG } & \text { let-PARTICIP } & \text { letter }\end{array}$

'The young man found the letter sent by his father.'

The close correspondence between accusative marking and object-verb agreement supports Dalrymple and Nikolaeva's (2011) assumption that differential object-verb agreement and differential object marking are two sides of the same phenomenon; both object-verb agreement and case-marking on the object encode the secondary topic role of the object. In that case, however, the lack of accusative marking on 1st and 2 nd person objects and on objects anchored to a 1st or 2nd person possessor is the equivalent of the Inverse Agreement Constraint, i.e., a manifestation of the Inverse Topicality Constraint, harmonizing the structural hierarchy and the relative topicality of the primary and secondary topics.

The type of constraint observed in Eastern Mansi, restricting the assignment of accusative case to 3rd person nominals, is known cross-linguistically as the Person-Case Constraint (cf. Bonet 1991, Anagnostopoulou 2003, etc.).

The Person-Case Constraint attested in Eastern Mansi is also present in Hungarian. Though object-marking by a $-t$ suffix is obligatory in Hungarian, the 1 st and 2 nd person singular pronouns bear no $-t$ (they only bear a possessive suffix): ${ }^{6}$

\footnotetext{
${ }^{6}$ Hungarian has lost the determiner-like use of possessive suffixes. The possessive morphemes of 1 st and 2nd person object pronouns are linguistic fossils. They may have survived because the possessive-marked caseless 1st and 2nd person singular pronouns have been reanalyzed as expletive forms standing for the accusative elements of the pronominal paradigm. However, the possessive morphemes have also survived on 1st and 2nd person plural object pronouns, where they are followed by an accusative ending:
}

(i) mi-nk-et ti-tek-et we-1PL-ACC $\quad$ you $\mathrm{PL}-2$ PL-ACC 'us' 'you PL $^{-A C C}$ ' 
(35)

\begin{tabular}{|c|c|}
\hline eng-em ${ }^{7}$ & $m i-n k-e t$ \\
\hline I-1sG 'me' & we-1sG-ACc 'us' \\
\hline tég-ed & tit-ek-et \\
\hline \multirow[t]{5}{*}{ you-2SG 'you.ACC' } & you $_{\mathrm{PL}}-2 \mathrm{PL}-\mathrm{ACC}$ ' $\mathrm{you}_{\mathrm{PL}}-\mathrm{ACC}$ ' \\
\hline & $o-t$ \\
\hline & (s)he-ACC \\
\hline & $o ̈-k-e t$ \\
\hline & (s)he- PL-ACC 'them' \\
\hline
\end{tabular}

The Person-Case effect is also attested, albeit in a weaker form, if the object has a 1SG or 2SG possessor. In that case, the accusative $-t$ can be omitted optionally:

\section{Összetörték az autó-m(-at) lautó-d(-at).}

broke.3PL the car-1SG(-ACC)/car-2SG(-ACC)

'They broke my car/your car., 8

The facts that Eastern Mansi has both differential object-verb agreement restricted by the Inverse Agreement Constraint, and differential accusative marking restricted by the PersonCase Constraint, and Hungarian has preserved both the Inverse Agreement Constraint constraining differential object-verb agreement and the Person-Case Constraint constraining differential accusative marking suggest that differential object-verb agreement and differential accusative marking coexisted in the Ugric languages. As has been clarified by Nikolaeva (2001), Skribnik (2001), Dalrymple and Nikolaeva (2011), Sipőcz (2013), Virtanen (2014; 2015), etc., object-verb agreement in Khanty and Mansi encodes the topic position of the object in syntactic structure, and its topic role in information structure. The Inverse Agreement Constraint is, in fact, an Inverse Topicality Constraint, ensuring that in sentences with two topics, the structurally lower, secondary topic should not outrank the primary topic

\footnotetext{
${ }^{7}$ - $g$ - in engem and téged is not part of either the pronominal stem or the possessive agreement suffix. Historical linguists suspect that it is a derivational suffix. I regard it as an epenthetic consonant. Marcel den Dikken assumes (p.c.) that it is the relic of the reflexive morpheme mag 'core, self'.

${ }^{8}$ The lack of accusative marking on 1 st and 2nd person singular pronominal objects and on lexical objects with a 1 st or 2 nd person possessor is related in an intricate theory by den Dikken (2004).

${ }^{8}$ The lack of accusative marking on 1 st and 2 nd person singular pronominal objects and on lexical objects with a 1 st or 2 nd person possessor is related in an intricate theory by den Dikken (2004).
} 
in topicality. If the Person-Case Constraint is another manifestation of the same constraint, then it should also share its function.

\section{The Person-Case Constraint across languages}

The phenomenon called Person-Case Constraint has been observed mostly in ditransitive constructions of languages that have weak or clitic pronouns, or rich agreement (Bonet 1991; 2007, Albizu 1997, Béjar \& Rezac 2003; 2009, Rezac 2008; 2011, Nevins 2007; 2011, Anagnostopoulou 2003; 2008, etc.). It requires that the direct object should not be higher ranked in the animacy hierarchy than the indirect object. E.g.

a. On me le montrera.

one me.DAT it.ACC show.FUT.3SG

'They will show it to me.'

$$
\begin{array}{rll}
\text { b. }^{*} \text { On } & \text { me lui } & \text { montrera. }^{9} \\
\text { one } & \text { me.ACC him.DAT } & \text { show.FUT.3SG }
\end{array}
$$

'They will show me to him.

The strong version of the Person-Case Constraint requires direct objects to be 3 rd person. The weak Person-Case Constraint allows 1st person-2nd person and 2nd person-1st person dative-accusative combinations, as well. ${ }^{10}$ The ultra-strong version allows a 2 nd person accusative clitic in the company of a 1st person dative clitic, but rules out a 1st person accusative clitic in the company of a 2 nd person dative clitic (Nevins 2007).

Some of the explanations of the Person-Case Constraint, e.g., Bonet (1991), analyze it as a morphological constraint. According to Bonet (1991), both the constraint ruling out dative + accusative clitic combinations where the accusative is other than third person, and the repair strategies deleting the violating features are morphological. She discusses three types of repair: (i) replacing the dative clitic with a strong pronoun: (French)

\footnotetext{
${ }^{9}$ As argued by Anagnostopoulou (2008), the underlying clitic order is always Dative $>$ Accusative. The inverse order can result, e.g., from a templating arrangement of features in morphology.

${ }^{10}$ In Bonet's (1991) formulation: STRONG VERSION: the direct object has to be third person WEAK VERSION: if there is a third person it has to be the direct object.
} 
Paul I.ACC show. FUT.3SG to him

'Paul will introduce me to him.'

(ii) replacing the animate dative clitic with an inanimate clitic devoid of person and number features:
Al president, me $* h i \quad / l i$ ha recomanat en Miquel. to.the president I.ACC he.DAT/there has recommended the Miguel 'As for the president, Miquel has recommended me to him' (Catalan)

(iii) replacing the 1 st or 2 nd person clitic with a reflexive, which triggers 3 rd person agreement (Georgian).

Albizu (1997), however, presented convincing evidence that the Person-Case Constraint operates in syntax. It is sensitive to whether the clause is $+/$-finite, whether the dative is thetamarked by the verb or is an ethical dative; it is sensitive to locality and c-command; at the same time, it is not dependent on morphological case, as it can affect dative-accusative, ergative-absolutive, and ergative-dative combinations alike.

Ormazabal \& Romero (2007) found that in some languages (the Leísta dialect of Spanish, KiRimi, Mohawk), the Person-Case Constraint is sensitive to animacy. Their version of the Person-Case Constraint states that if object agreement encodes animacy, no other argument can be licensed through verbal agreement.

A widespread family of explanations share the view that the Person-Case Constraint is elicited because the dative and accusative (or ergative and dative, etc.) pronouns attempt feature-checking with the same functional head (Anagnostopoulou 2003, Béjar \& Rezac 2003; 2009, Adger \& Harbour 2007, Nevins 2007; 20011). In Anagnostopoulou's (2003) theory, dative and accusative weak pronouns compete for agreement with v. Agreement involves the checking of person and number features, which are stipulated to be distributed among accusative and dative pronouns as follows:
(40) 1,2, ACC: + person, number
1,2, DAT: +person
3 ACC: number
3 DAT: -person 
Feature checking procedes cyclically. In languages with a strong Person-Case Constraint, first DAT checks features with $\mathrm{v}$, and then ACC checks features with it. The derivation converges if DAT checks the person feature of $\mathrm{v}$, and ACC checks its number feature. If ACC is 1st or 2nd person, the person feature of $\mathrm{v}$ cannot be checked, and the derivation crashes - because only complete phi-checking results in structural Case checking. Languages with a weak Person-Case Constraint have Multiple Agree, i.e., person is checked simultaneously against both objects, which can only take place under non-conflicting feature specifications of the agreement elements.

The model of Nevins $(2007 ; 2011)$ derives person complementarity effects through intervention, by means of Multiple Agree. The probe is situated above both goals, and establishes a simultaneous Agree relationship with both of them, subject to the Continuous Agree constraint, which requires that valuation of the probe with a certain feature should not skip any of the arguments along its path. A probe required to agree with a [+participant] will satisfy Continuous Agree in $1 \mathrm{st}>3 \mathrm{rd}$ but not in $* 3 \mathrm{rd}>1$ st contexts because the [-participant] 3rd person interrupts the continuous span of Agree in the latter case. By contrast, two [+participant] features (e.g. 1st $>2$ nd or $2 \mathrm{nd}>1 \mathrm{st}$ ) will satisfy Continuous Agree in either configuration, because the path of Agree does not skip a [+participant] argument in either case. In Kashmiri, the Person-Case Constraint affects the subject and the object, because clitic movement shifts the object into the same Agree domain as the subject.

Béjar and Rezac (2009) found several languages, among them Basque, Georgian, Karok, and the Uralic Erza Mordvinian, where the arguments competing for agreement with a single probe, subject to the Person-Case Constraint, are the internal argument and the external argument. The primary controller of verbal agreement is the internal argument, hence the probe first searches for a goal downward in the syntactic tree, and if this search has not resulted in the complete valuation of its features (e.g., if the object is 3 rd person), it searches upward. An object completely valuing the features of a probe renders it inactive for upward agreement. Since the features of a 1 st person pronominal entail the features of a 3 rd person pronominal, downward agreement with a first person direct object renders the probe inactive for agreement with a 3rd person subject, which evokes a repair strategy. The possible repair strategies include the addition of an inverse element to the $\mathrm{V}$, which functions as an additional probe for the external argument (Mohawk), or a special case on the direct object, which allows agreement to be controlled by the external argument (Kashmiri). Non-agreement repair strategies include the use of another related numeration such as the passive, the use of a nonagreeing strong pronoun, or the removal of the offending agreement. 
In the functional-typological theory of Haspelmath (2004), the Person-Case Constraint correlates persons and thematic roles instead of persons and cases. The version expressing preference for recipients to be 1 st or 2 nd person and themes to be 3 rd person is called the Ditransitive Person-Role Constraint, and the version expressing preference for agents to be 1st or 2nd person and themes to be 3rd person is called the Monotransitive Person-Role Constraint. Haspelmath claims on the basis of data from dozens of languages that the constraint is universal but extra-grammatical. The claim that it is extragrammatical is based on the following facts: it is not an absolute constraint, as its violations are often not ungrammatical, merely dispreferred; it is manifested in many different ways across languages (it can affect agreement suffixes, clitics, weak pronouns of 1 st and 2 nd person, but rarely also animate 3rd person pronouns, and even animate, singular, definite full DPs; the position of the pronouns can be irrelevant); etc. A further fact that grammatical explanations cannot explain is why strong pronouns are exempt from the Person-Case Constraint.

According to Haspelmath, what underlies the constraint is the person scale in (41) and the semantic role scale in (42):

(41) Person scale:

1 st $/ 2$ nd person $>3 \mathrm{rd}$ person

(42) Semantic role scale:

Agent $>$ Recipient $>$ Patient/Theme

Person-role associations are more harmonic when high persons are associated with high roles, and when low persons are associated with low roles, because both the person scales and the role scales are strongly correlated with animacy and topicality. Harmonic associations are more natural, hence more frequent, consequently they tend to grammaticalize (as also suggested in connection with similar Romanian data by Farkas and Kazazis (1980)). The harmonic association of role and person scales can be subsumed under a larger generalization: the Person-Role Constraints are special cases of the Topicality-Role Constraint.

\section{Explanations of the Person-Case Constraint and the Uralic data}

As has been argued in sections 2-4, the ban on agreement with 1st and 2nd person pronouns in Hungarian, Eastern Khanty and the Samoyedic languages is a manifestation of the same constraint that bans accusative assignment to 1st and 2nd person objects in Eastern Mansi and 
Hungarian, and which is known as the Person-Case Constraint in the Indo-European languages. The question is whether the explanations of the Person-Case Constraint surveyed in section 5 can also account for the Ugric and Samoyedic facts.

The Person-Case Constraint and Inverse Agreement Constraint in the Uralic languages are sensitive not only to the the person and number of the pronouns affected, but also to their grammatical function and their relative structural prominence, hence the morphological approach of Bonet (1991) does not seem to be adequate.

The theory of Cyclic Agree has been adapted to Hungarian by Bárány (2015a,b). In his (2015a) approach, the $v$ first enters into an Agree relation with the direct object. When the direct object is $3 \mathrm{rd}$ person, it only values the person feature of the probe, leaving its participant and speaker features unvalued. This makes the probe extend its search space to the external argument, which values these features in a second cycle. Thus the subject and the object value a single probe together, which is spelled out as the objective conjugation. When the direct object has the features [+person, + probe unvalued. For the subject to be licensed, a repair strategy is employed: an additional probe enters into an Agree relation with the subject alone. This is spelled out as the so-called subjective conjugation, showing agreement only with the subject.

What this theory and other versions of the Cyclic Agree approach cannot predict in its entirety is the paradigm in (6)-(7), rewritten here as (43)-(44). When both the subject and the object are 1st person, or both are 2nd person, the singular subject - plural object configuration triggers object agreement, whereas the plural subject - singular object configuration blocks it:

a. Én minket ajánl-om /*ajánl-ok.

I us recommend-OBJ.1SG/recommend-1SG

'I recommend us.'

b. Te titeket ajánl-od /*ajánl-asz?

you $_{\mathrm{SG}} \mathrm{you}_{\mathrm{PL}}$.ACC recommend-OBJ.2SG/recommend-2SG

'Do you ${ }_{\mathrm{SG}}$ recommend you guys?

(44) a. Mi engem választ-unk/*választ-ju-k.

we me elect-1PL /elect- OBJ-1PL

'We elect me.'

b. Ti téged választ-otok/*választ-já-tok?

you $_{\mathrm{PL}} \mathrm{you}_{\mathrm{SG}}$. ACC elect-2SG /elect- OBJ-2SG 
'Do you guys elect you $\mathrm{SG}_{\mathrm{SG}}$ ?

If plural is a privative feature, as argued by Nevins (2011) and others, a plural 1st or 2nd person object checks every feature of the probe. In such cases, Bárány (2015a) predicts an additional probe for the subject, which ought to result in the subjective conjugation; however, only the objective conjugation (i.e., object-verb agreement) is possible, as shown in (43).

Bárány (2015b, Chapters 2-4) puts forth a modified version of this theory of Cyclic Agree. As in the previous version, the objective conjugation, agreeing with both the object and the subject, arises when both the object and the subject participate in valuing the features of $\mathrm{v}$. If the object is 1 st or 2 nd person, valuing all the features of $v$, the subject establishes an Agree relation with the case and number features of T. In this case, verb morphology shows agreement only with the subject, but v-object agreement, too, is claimed to take place syntactically. This claim is based on the following premise:

(44) Object agreement, object drop, and secondary predication

Object agreement allows for object drop and modification of the dropped object by a secondary predicate. (Bárány 2015b: 117)

As demonstrated by Bárány, not only 3rd person, but also 1st and 2nd person object pronouns can be dropped in Hungarian, and not only 3rd person, but also 1st and 2nd person object pronouns can function as subjects of secondary predicates, e.g.:

\section{(45) Lát-ott pro részegen. \\ see-PAST.3SG pro drunk \\ '(S)he saw me/you drunk.'}

However, the assumption in (44) leads to a contradiction. Bárány claims that indefinite 3rd person objects have no person feature, and cannot enter Agree with v. Nevertheless, they can be represented by a silent pro, which can be modified by a secondary predicate - especially if the referent is inanimate (46), but often also when it is animate (47):
(46)
"Van sör az autó-ban. Kérsz pro?" is beer the car-in want-2SG
'There is beer in the car. Do you want any?' 
"Nem kérek pro. / Meleg-en nem kérek pro."

not want warm-ADV not want

'I don't want any. / I don't want any warm.'

"Jelentkeztek okos doktoranduszok."

applied bright PhD-students

'Bright PhD students applied.'

"Csak ajánlólevél-lel vesz-ünkfel pro."
only letter.of.recommendation-with take-1PL on
'We only admit anybody with a letter of recommendation.'

Bárány's (2015b) theory treats verbal agreement morphemes of both the subjective and the objective conjugation as simple suffixes, whose distribution is determined by spell-out rules often subject to impoverishment (underspecification). This framework can handle apparently idiosyncratic cases like those in (43)-(44) easily, even if not in a principled manner (the impoverishment rules assumed bleed the insertion of the form showing subject agreement when first and second person singular subjects have plural objects in the same person). ${ }^{11}$

An insurmountable problem for any version of the Cyclic/Multiple Agree theory is the fact that in Eastern Mansi, not only 1st and 2nd person objects are subject to the Person-Case Constraint, but also objects anchored to a 1st or 2nd person possessor, as illustrated by (32) rewritten here as (48):

(48) Ääk-øn komøly woåxtl-øs-løn!

uncle-2SG how leave-PAST-OBJ.2SG

'How could you leave your uncle!' ～(Eastern Mansi, Virtanen 2014: (21))

Although Hungarian generalized object marking to all objects at least 800 years ago, it has preserved a fossilized Person-Case Constraint that represents the same problem: in addition to 1st and 2nd person objects, also objects anchored to a 1st or 2nd person possessor can be

\footnotetext{
${ }^{11}$ Bárány (2015b: 148) claims that these impoverishment rules can be motivated semantically. Namely, when the subject of the clause type in question is singular, its referent is part of the (plural) referent of the object. In this sense, the predicate is reflexive, and reflexive objects containing a 3rd person stem, among them magam, 'myself', literally 'my core', magad 'yourself/your core', elicit object agreement. When the subject is in the plural, and the object is in the singular, the subject's referent is not included in the object's referent and the predicate is not reflexive. However, the objects in (43)-(44) are clearly personal pronouns and not reflexives.
} 
caseless $(49 \mathrm{a}, \mathrm{b})$. (A caseless object with a 3rd person possessor is highly ungrammatical - see $(49 \mathrm{c})$.)

a. Ök ismer-i-k a család-om. they know-OBJ-3PL the family-1SG 'They know my family.'

b. A diákok olvas-t-á-k a könyv-ed. ${ }^{12}$ the students read-PAST-OBJ-3PL the book-2SG 'The students read your book.'

c. ${ }^{* *}$ A diákok ismer-i-k a könyv-e. the students know-OBJ-3PL the book-3SG

'The students know his book.'

In (48) and (49a,b), the caseless object is formally 3rd person, hence the theories of Cyclic/Multiple Agree do not predict the triggering of the Person-Case Constraint, i.e., they cannot account for the blocking of the case-marking of the object. The present proposal, however, can easily explain this phenomenon. What triggers the Person-Case Constraint in this framework is a contradiction between the structural hierarchy of a topicalized subject and object and the ranking of their referents in the Animacy Hierarchy. Since a 3rd person object with a 1st or 2nd person possessor is in most cases a part or a belonging of the speaker or the listener, it can be identified with a 1st or 2nd person referent, hence it can be understood to be more prominent in the Animacy Hierarchy than a 3rd person subject.

This approach is related to Haspelmath's (2004) analysis of the Person-Case Constraint. It shares Haspelmath's view that the elements subject to the Person-Case Constraint represent topical arguments competing for dominance in the same (external or internal) topic domain. However, the Khanty and Mansi double object constructions make it clear that the constraint is not role-dependent as assumed by him; it affects subjects and objects, whatever their

\footnotetext{
${ }^{12}$ Even Finnish has preserved this relic of the Person-Case Constraint; there is no accusative in Finnish after 1st and 2 nd person possessive endings:
(i) a. Tapa-si-n poika-ni. meet-PAST-1SG boy-POSS1SG
vs. b. Tapa-si-n poja-n. meet-PAST-1SG boy-ACC
' met my son'
'I met a boy'

(Virtanen 2015: 43)
} 
thematic roles. That is, the Uralic facts refute his claim that the Person-Case Constraint is extragrammatical. The repair strategy it triggers in the Ugric languages is also clearly syntactic: an object that is more prominent in the topicality hierarchy than the subject cannot be externalized; it remains inside the verb phrase, where it is interpreted as an information focus.

What the Inverse Topicality Constraint, manifested as the Inverse Agreement Constraint and/or the Person-Case Constraint, correlates in the Uralic languages is structural hierarchy and discourse-functional hierarchy; that is, it is a constraint on the syntaxsemantics/pragmatics interface. This approach, similar to Haspelmath's explanation, can resolve the contradiction between the generality of the constraint in the languages of the world and its high variability as regards its targets, its licensing conditions, and its manifestations. What is general is the tendency for information structure to be manifested in syntactic structure. In the Uralic languages in which the Inverse Topicality Constraint is active, syntactic structure and information structure are more or less fused. Information structure cannot overwrite the c-command relations of syntactic structure, for example, a topicalized object cannot c-command the subject in an active sentence. Consequently, the syntactic and discourse hierarchies of the constituents must be harmonized. If a language has developed syntactic means of expressing information structure independently of grammatical functions, the Inverse Topicality Constraint loses its role, but it can persist in the grammar as a linguistic fossils. This is what has happened in Hungarian. There can also be intermediate cases of various types. For example, a language can restrict the operation of the Inverse Topicality Constraint to a lower topic position above the vP; or it can preserve the constraint in a weaker form, the violation of which results in markedness instead of ungrammaticality.

A potential source of variation is the different segmentation of the Animacy Hierarchy in (2) across languages. Languages with a weak Person-Case Constraint contract 1st and 2nd person in the hierarchy. In languages where the Person-Case Constraint is sensitive to the animacy of the constituents, the 3rd person level of the hierarchy is further divided into [+animate] and [-animate] levels.

The strategies repairing violations of the Person-Case Constraint also follow naturally in the proposed framework. The syntactic hierarchy and the animacy hierarchy can be harmonized manipulating the syntactic structure, e.g., by removing a violating constituent from the topic domain - into the emphatic clause-final focus position in the Romance languages, and into the immediately preverbal position in Ugric. Other strategies affect the ranking of the elements in the Animacy Hierarchy. The replacement of a 1st or 2nd person 
clitic by a (3rd person) reflexive downgrades the structurally less prominent participant in the Animacy Hierarchy. The replacement of a weak pronoun by a locative removes the pronoun from the Animacy Hierarchy of discourse participants.

The claim that the Person-Case Constraint in various Indo-European languages is a manifestation of the Inverse Topicality Constraint presupposes that the process of clitic doubling occasionally eliciting the constraint serves the purpose of encoding the topic role of the object in those languages, too. Claims to that effect have been put forth by Kallulli (2008), Dočekal and Kallulli (2012), and others.

\section{References}

Aissen, Judith. 1999. Markedness and subject choice in Optimality Theory. Natural Language and Linguistic Theory 17. 673-711.

Albizu, Pablo. 1997. Generalized Person-Case Constraint: A case for a syntax-driven inflectional morphology. In Amaya Mendikoetxea \& Myriam Uribe-Etxebarria (eds.), Theoretical issues on the Morphology-Syntax Interface, 1-34. San Sebastian: ASJU Gehigarriak XL.

Anagnostopoulou, Elena 2003. The Syntax of Ditransitives. Evidence from Clitics. Berlin /New York: Mouton de Gruyter.

Anagnostopoulou, Elena 2008. Notes on the Person Case Constraint in Germanic. In Roberta D’Alessando, Susann Fischer \& Gunnar Hrafn Hrafnbjargarson (eds), Agreement Restrictions, 15-48. Berlin: Mouton de Gruyter.

Bárány, András. 2015a. Inverse agreement and Hungarian verb paradigms. In Katalin É. Kiss, Balázs Surányi \& Éva Dékány (eds.), Approaches to Hungarian 14, Papers from the 2013 Piliscsaba Conference, 37-64. Amsterdam/Philadelphia: John Benjamins.

Bárány, András. 2015b. Differential object marking in Hungarian and the morphosyntax of case and agreement. PhD Dissertation. Cambridge: Cambridge University.

Béjar, Susan \& Milan Rezac. 2003. Person licensing and the derivation of PCC effects. In Ana Teresa Pérez-Lenoux \& Yves Roberge (eds.), Romance Linguistics: Theory and Acquistion, 49-62. Amsterdam: John Benjamins.

Béjar, Susan \& Milan Rezac. 2009. Cyclic agree. Linguistic Inquiry 40. $35-73$.

Bonet, Eulàlia. 1991. Morphology after Syntax. PhD. dissertation. Cambridge, MA: MIT. Bonet, Eulàlia. 2007. The Person-Case constraint and repair strategies. In Roberta d'Alessandro, Susann Fischer, \& Gunnar Hrafn Hrafnbjargarson (eds.), Person Restrictions. Berlin/New York: Mouton de Gruyter. 
Brown, Robert. 1988. Waris case system and verb classification. Language and Linguistics in Melanesia 19. 37-80.

Comrie, Bernard. 1980. Inverse verb forms in Siberia: Evidence from Chukchee, Koryak and Kamchadal. Folia Linguistica 1. 61-74.

Dalrymple, Mary \& Irina Nikolaeva. 2011. Objects and Information Structure. Cambridge: Cambridge University Press.

den Dikken, Marcel. 2004. Agreement and 'clause union'. In Katalin É. Kiss \& Henk van Riemsdijk (eds.), Verb Clusters: A study of Hungarian, German and Dutch, 445-498. Amsterdam/Philadelphia: John Benjamins. ‘ den Dikken, Marcel, Anikó Lipták \& Zsófia Zvolenszky. 2001. On inclusive reference anaphora: New perspectives from Hungarian. In Karine Megerdoomian \& Leora Anne Bar-el (eds.), WCCFL 20: Proceedings of the 20th West Coast Conference on Formal Linguistics, 137-149. Somerville, MA: Cascadilla Press.

Dočekal Mojmír \& Dalina Kallulli. 2012. More on the semantics of clitic doubling: principal filters, minimal witnesses, and other bits of truth. In Christopher Piñón (ed.), Empirical Issues in Syntax and Semantics 9, 113-128. http://www.cssp.cnrs.fr/eiss9/

É. Kiss, Katalin. 2005. The inverse agreement constraint in Hungarian - a relic of a UralicSiberian Sprachbund? In Hans Broekhuis, Norbert Corver, Jan Koster, Riny Huybregts \& Ursula Kleinhenz (eds.), Organizing Grammar. Linguistic Studies in Honor of Henk van Riemsdijk, 108-116. Berlin: Mouton de Gruyter.

É. Kiss, Katalin. 2012. Null pronominal objects in Hungarian: A case of exaptation. Acta Linguistica Hafniensia 44.192-206.

É. Kiss, Katalin. 2013. The Inverse Agreement Constraint in Uralic languages. Finno-Ugric Languages and Linguistics 2 (1). 2-21.

Escandell-Vidal, M. Victoria. 2009. Differential object marking and topicality. The case of Balearic Catalan. Studies in Language 33(4). 832-885.

Farkas, Donka \& Kostas Kazazis. 1980. Clitic pronouns and topicality in Rumanian. Chicago Linguistic Society 16. 75-82.

Forsberg, Ulla-Maija. 2007. Eastern mansi (Konda) Grammar. http://www.google.hu/url?sa $=t \& r c t=j \& q=\&$ esrc $=$ s\&source $=$ web $\& c d=2 \& v e d=0 C C o Q F j A B \&$ url $=\mathrm{http} \% 3 \mathrm{~A} \% 2 \mathrm{~F} \% 2 \mathrm{Fbabel} . \mathrm{gwi}$. unimuenchen.de\%2Fmedia\%2Fdownloads\%2Fgrammar\%2FEasternMansi\%2FEasternMansiGra mmar.pdf\&ei=HqDoVIHqC8 KaJq6gvgB\&usg=AFQjCNEEQpoC2IktjlPIMPVeYK2zA4m $\underline{\text { ORg\&bvm }=\text { bv. } 86475890, \text { d.d } 2 \mathrm{~s}}$ 
Givón, Talmy. 1975. Topic, pronoun, and grammatical agreement. In Charles Li \& Sandra Thompson (eds.), Subject and Topic, 149-188. New York: Academic Press.

Givón, Talmy. 1975. Topic Continuity in Discourse. Amsterdam: John Benjamins.

Gulya, János. 1970. Aktiv, Ergativ und Passiv im Vach-Ostjakischen. In Wolfgang Schlachter (ed.), Symposium uber Syntax der uralischen Sprachen. Göttingen: Van den Hoock and Ruprecht.

Haspelmath, Martin. 2004. Explaining the Ditransitive Person-Role Constraint. Constructions 2/2004. www.constructions-online.de. urn:nbn:de:0009-4-359. ISSN 1860-2010.

Havas, Ferenc. 2008.Unmarked object in the Uralic languages: a diachronic typological approach. Linguistica Uralica. 43/1. 1-33.

Honti, László. 2009. Tủnődések tárgyas igeragozásunk kialakulásáról [Reflections on the evolution of our objective conjugation]. Nyelvtudományi Közlemények 106. 132-146.

Kallulli, Dalina. 2008. Clitic doubling, agreement, and information structure. In Dalina Kallulli \& Liliane Tasmowski (eds.), Clitic doubling in the Balkan languages, 227-255. Amsterdam: John Benjamins.

Moravcsik, Edith. 1974. Object-verb agreement. Working Papers on Language Universals 15. Stanford: Committee on Linguistics.

Nevins, Andrew. 2011. Multiple Agree with clitics: Person complementarity vs. omnivorous number. Natural Language \& Linguistic Theory 29 (4). 939-971

Nikolaeva, Irina. 1999. Ostyak. Languages of the World/Materials 305. München: Lincom Europa.

Nikolaeva, Irina. 2001. Secondary topic as a relation in information structure. Linguistics 39. $1-49$.

Nikolaeva, Irina. 2002. Possessive affixes in the pragmatic structuring of the utterance: Evidence from Uralic. In Bernard Comrie \& Pirkko Suihkonen (eds.), International Symposium on Deictic Systems and Quantification. Izhevsk. Amsterdam/Philadelphia: John Benjamins.

Nikolaeva, Irina. 2014. A Grammar of Tundra Nenets. Berlin/New York: Mouton de Gruyter. Ormazabal, Javier \& Juan Romero. 2007. The Object Agreement Constraint. Natural Language and Linguistic Theory 25. 315-347.

Pápay, József. 1906-8. Északi-osztják nyelvtanulmányok [Northern Ostyak linguistic studies]. Nyelvtudományi Közlemények 36-38. 345-98; 52-79; 164-95; 258-75; 111-50; 313-29. 
Rebrus, Péter. 2000. Morfofonológiai jelenségek [Morphophonological phenomena]. In Ferenc Kiefer (ed.), Strukturális magyar nyelvtan 3. Morfológia, 763-948. Budapest: Akadémiai Kiadó.

Rezac, Milan. 2008. The syntax of eccentric agreement: The Person Case Constraint and absolutive displacement in Basque. Natural Language and Linguistic Theory 26. 61-106.

Rezac, Milan. 2011. Phi-features and the modular architecture of language. Dordrecht: Springer.

Siewierska, Anna. 2004. Person. Cambridge: Cambridge University Press.

Skribnik, Elena. 2001. Pragmatic structuring in Northern Mansi. In Tönu Seidenthal (ed.), Congressus Nonus Internationalis Fenno-ugristarum. Pars IV. Dissertationes sectionum: Linguistica III. Tartu: Tartu University.

Sipőcz, Katalin. 2012 Ditranzitív igék a manysiban [Ditransitive verbs in Mansi]. Nyelvtudományi Közlemények 109. 123-136.

Virtanen, Susanna. 2014. Pragmatic object marking in Eastern mansi. Linguistics 52(2). 391413.

Virtanen, Susanna. 2015. Transitivity in Eastern Mansi. PhD dissertation. University of Helsinki. 